\title{
EFEKTIFITAS KOMUNIKASI INTERPERSONAL ANTARA PIMPINAN DAN STAF DALAM MENJALIN HUBUNGAN KERJA PADA DINAS PEMBERDAYAAN PEREMPUAN PERLINDUNGAN ANAK DAN KELUARGA BERENCANA KABUPATEN SUPIORI
}

\author{
Hepi Hastuti \\ Program Studi Ilmu Komunikasi, Fakultas Ilmu Sosial dan Ilmu Politik \\ Institut Ilmu Sosial dan Ilmu Politik YAPIS Biak \\ Email : hepi_hastuti@iyb.ac.id
}

\begin{abstract}
Abstrak
Komunikasi menjadi titik yang penting karena segala proses perencanaan dan perorganisasian tidak dapat dijalankan dengan baik tanpa adanya komunikasi. Penelitian ini bertujuan untuk mengetahui Efektifitas Komunikasi Interpersonal Antara Pimpinan Dan Staf Dalam Menjalin Hubungan Kerja Pada Dinas Pemberdayaan Perempuan, Perlindungan Anak Dan Keluarga Berencana Kabupaten supiori. Penelitian ini menggunakan pendekatan kualitatif. Teknik pengumpulan data yang digunakan seperti; observasi,wawancara, dan dokumentasi. Metode analisis yang digunakan adalah analisis kualitatif. Hasil penelitian menunjukkan bahwa Efektifitas Komunikasi Interpersonal Antar Pimpinan Dan Staf Dalam Menjalin Hubungan Kerja Pada Dinas Pemberdayaan Perempuan, Perlindungan Anak Dan Keluarga Berencana kabupaten supiori cukup efektif berdasarkan lima indikator kualitas komunikasi interpersonal yaitu harus memiliki sikap keterbukaan, empati, sikap mendukung, sikap positif dan sikap kesetaraan.
\end{abstract}

Kata Kunci: Efektifitas, Komunikasi Interpersonal.

\section{PENDAHULUAN}

Komunikasi merupakan aktivitas yang tidak asing lagi dalam kehidupan manusia. Dalam melangsungkan hidupnya manusia butuh berkomunikasi. Satu ungkapan yang populer di lingkungan kita bahwa manusia adalah makhluk sosial yang artinya tidak ada seorangpun manusia yang bisa hidup sendiri, karena itu setiap individu butuh interaksi dengan sesama manusia yang ada disekelilingnya. Kebutuhan berinteraksi dengan orang lain ini hanya dapat dilakukan dengan komunikasi. Lewat komunikasi, manusia berhubungan satu sama lain dengan berbagai tujuan. Sehingga komunikasi sangat penting apa lagi didalam organisasi yang masing-masing individu saling berinteraksi,sehingga pesan yang disampaikan maupun diterima mendapat respon timbal balik dari interaksi tersebut.

Komunikasi setidaknya sudah mengandung kesamaan makna antara dua belah pihak, namun kegiatan komunikasi tidak hanya informatif, yakni agar orang lain mengerti dan tahu segala informasi yang di percakapkan atau diberikan melainkan komunikasi juga sampai tataran persuasif yaitu orang lain dapat dipengarui dengan informasi sehingga timbul keyakinan, bila berada didalam sebuah organisasi komunikasi mampu membangkitkan gairah kerja antara pimpinan dan bawahan yang sesuai tujuan organisasi. Tanpa komunikasi, organisasi apapun tak akan menjadi seperti yang diharapkan dan tak akan bisa mencapai tujuannya secara efektif. Besar kecilnya 
sebuah organisasi di dalamnya pasti dibangun, dipelihara dan ditumbuhkan sistem komunikasi karena dengan adanya komunikasi yang baik dalam suatu organisasi akan memudahkan setiap kegiatan yang dilakukan dan memberikan kelancaran bagi tercapainya tujuan yang diharapkan. Oleh karena itu, hubungan interpersonal yang kurang harmonis yang terjalin di antara sumber daya manusia dalam perusahan juga dapat berpotensi menciptakan kerja yang kurang menyenangkan dan praktis mengganggu produktivitas kerja. Untuk menciptakan hubungan yang harmonis diperlukan praktik komunikasi mulai dari atasan sampai dengan staf/karyawan.

Dinas Pemberdayaan Perempuan, Perlindungan Anak dan Keluarga Berencana, merupakan salah satu instansi pemerintahan yang juga mengalami masalah dalam komunikasi interperonal antara pimpinan-bawahan sehingga proses penyampaian tujuan organisasi menjadi terhambat, karena baik pimpinan sendiri atau para pegawai mempunyai masalah berkenan dengan tugas maupun menyangkut diluar tugas masing-masing. Peneliti ingin mengambil titik fokus di sub bagian umum dan kepegawaian yang mempunyai tugas merencanakan operasional, mengola, mengendalikan, mengevaluasi, melaporkan pelaksanaan tugas lingkup kesekretarian dan mengkoordinasikan penyelenggaraan kegiatan bidang-bidang lingkup Dinas Pemberdayaan Perempuan, Perlindungan Anak dan Keluarga Berencana.Tak dapat dipungkiri bahwa para pegawai juga mempunyai masalah berkenan dengan tugas yang diembankan kepada mereka, maupun tentang peraturan yang diberlakukan oleh instansi. Hal ini sangat penting diketahui olen pimpinan untuk menunjang kelancaran proses komunikasi interpersonal para pegawai dan pimpinan.

Komunikasi menjadi titik yang penting karena segala proses perencanaan dan perorganisasian tidak dapat dijalankan dengan baik tanpa adanya komunikasi. Bentuk yang paling tepat digunakan untuk memelihara hubungan yang harmonis dan meminimalisir kesalahpahaman di antara sesama staf/karyawan maupun antara atasan dengan staf/karyawan adalah komunikasi interpersonal. Dengan komunikasi interpersonal, dapat dilakukan pendekatan secara langsung untuk menjelaskan berbagai pesan yang dapat menimbulkan kesalah interprestasi. Semakin banyak orang yang dapat diajak bekerja sama, maka semakin lancarlah pelaksanaan kegiatan dalam kehidupan sehari-hari, sebaliknya apabila ada seorang saja musuh, kemungkinan akan ada terjadi kendala. Dalam hal ini berarti proses komunikasi interpersonal yang terjadi pada setiap sumber daya manusia dalam dinas dapat memengaruhi tingkat kerja sama, solidaritas dan keharmonisan.

Dalam komunikasi interpersonal yang baik, bukan terletak pada masalah sering atau jarangnya komunikasi itu dilakukan, melainkan pada bagaimana komunikasi itu dilakukan. Kualitas komunikasi sangat perlu diperhatikan selama komunikasi berlangsung. Komunikasi interpersonal akan menunjukan tingkat kefektifannya ketika komunikator dan komunikan sudah saling terbuka. Keterbukaan merupakan pengungkapan diri itu sendiri adalah mengungkapkan reaksi atau tanggapan kita terhadap situasi yang sedang kita hadapi serta memberikan informasi tentang masa lalu yang relavan atau yang berguna untuk memahami tanggapan kita dimasa kini.(Satrio, 2010). 
Menurut Joseph Devito, karakteristik komunikasi interpersonal yang efekti menekan pada ketebukaan, empati, sikap mendukung, kesetaraan, dan sikap positif. Dari aspek-aspek ini kita kemudian dapat menurunkan prilaku-prilaku spesifik yang menandai komunikasi interpersonal yang efektif. (Joseph Devito 1997). Komunikasi interpersonal selalu ada di setiap organisasi, perusahan, masyrakat dan lain sebagainya. Menurut Devito (2009) komunikasi secara formal dapat diartikan sebagai proses penyampaian berita yang dilakukan oleh seseorang dan diterimannya berita tersebut oleh orang lain atau kelompok kecil dari orang-orang dengan suatu akibat dan umpan balik yang segera. Seperti di Dinas Pemberdayaan Perempuan, Perlindungan Anak dan Keluarga Berencana. Dinas ini terdiri atas:sub bagian umum dan kepegawaian. Terjalinnya keakraban antar sesama, terbentuknyasuatu kelompok awal mulanya adanya suatu interaksi komunikasi. Semakin aktif berkomuniaksi maka akan kuat tingkat hubungannya atau interpersonalnya karena seseorang akan semakin mengenal dari lawan bicaranya. Komunikasi merupakan suatu alat untuk hidup yang merupakan alat untuk hidup yang dibutuhkan tiap-tiap individu. Menurut Barelson dan Gari A. Steiner memaparkan bahwa individu membutuhkan informasi didalam hidupnya, sehingga komunikasi sebagai proses penyampaian suatu gagasan, emosional, bisa melalui suara, simbol atau gambar yang digunakan dalam kehidupannya (Riswandi, 2008).

\section{METODE PENELITIAN}

\section{Lokasi Penelitian}

Penelitian ini dilakukan pada Kantor Dinas Pemberdayaan Perempuan,
Perlindungan Anak, dan Keluarga Berencana Kabupaten Supiori.

\section{Jenis Penelitian}

Jenis penelitian yang penulis gunakan adalah penelitian deskriptif kualitatif yaitu metode yang dirancang untuk mengumpulkan informasi tentang keadaankeadaan nyata sekarang (sementara berlangsung). Tujuan utama menggunakan penelitian ini adalah untuk menggambarkan sifat suatu keadaan yang sementara berjalan pada saat penelitian dilakukan, dan memeriksa sebab-sebab dari masalah tertentu.

\section{Sumber Data}

Data diperoleh melalui observasi atau pengamatan langsung, yang mendalam kepada responden, yaitu dari pimpinan dan staf Dinas Pemberdayaan Perempuan, Perlindungan Anak, dan Keluarga Berencana. Data yang diperoleh dari catatan-catatan atau dokumen yang berkaitan dengan penelitian baik referensi buku, majalah dan berbagai literatur yangberkaitan dengan tema penelitian. Sumber data dapat diperoleh dari Kepala Kantor Dinas Pemberdayaan Perempuan, Perlindungan Anak, dan Keluarga Berencana Kabupaten Supiori, dimana peneliti dapat mengamati, bertanya atau membaca tentang hal-hal yang berkaitan dengan variabel yang diteliti.

\section{Tekhnik Pengumpulan Data}

Tekhnik pengumpulan data yang peneliti pakai adalah tekhnik pengumpulan data kualitatif. Pengumpulan data kualitatif berupa pengumpulan data dalam bentuk kalimat, kata dan gambar. Pelaksanaan teknik pengumpulan data dilakukan dengan: Observasi, wawancara (interview), studi 
kepustakaan (Libery Research), penelitian dokumen atau dokumen research.

\section{Tekhnik Analis Data}

Dalam penelitian kualitatif, data diperoleh dari berbagai macam sumber, dengan menggunakan teknik pengumpulan data yang bermacammacam (triangulasi), dan dilakukan secara terus menerus sampai datanya jenuh. Analisis data kualitatif adalah bersifat induktif, yaitu suatu analisis berdasarkan data yang diperoleh, selanjutnya dikembangkan pola hubungan tertentu atau menjadi hipotesis.

\section{HASIL DAN PEMBAHASAN}

\section{A. Efektifitas Komunikasi Interpersonal} Antara Pimpinan Dan Staf Dalam Menjalin Hubungan Kerja.

Dari Hasil wawancara Petronella Yembise mengatakan bahwa: “...........Saya sebagai pimpinan merasa hubungan komunikasi yang terjadi dilingkungan kerja bisa dikatakan cupuk baik, akan tetapi saya berharap agar bawahan juga harus sering melakukan interaksi dengan saya dan terbuka dengan saya soal pekerjaan yang saya berikan, agar dalam pekerjaannya yang saya berikan tidak akan terjadi masalah atau kendala yang dihadipi bawahan saya, kalau menurut saya sebagai pimpinan dalam komunikasi harus ada keterbukaan dan kejujuran. Kalau pegawai disini tidak terbuka dalam bekerja pasti ini akan menjadi kendala atau masalah tersendiri yang dihadapi oleh pegawai, dan saya rasa komunikasi yang terjadi disini berlangsung dengan baik-baik saja"'.

Dari hasil wawancara diatas menurut penulis sebagai seorang atasan harus ada keterbukaan dan kejujuran dari atasan kebawahan seperti mengenai ide-ide ataupun saran dan kritik. Penulis juga mewawancarai sekretaris yaitu ibu Annela F Sada Sebagai berikut.

“..........Sebagai bawahan jelas saya ingin menjalin komunikasi dengan atasan agar dalam pekerjaan yang saya kerjakan dapat diselesaikan dengan baik. Dan kalau tanpa adanya komunikasi yang baik antara saya dengan atasan bisa saja pekerjaan yang diberikan kepada saya tidak akan terselesaikan dengan baik dan tidak dapat mencapai target. Oleh karena itu keterbukaan antara atasan dan bawahan adalah kunci berkomunikasi. Saya sebagai bawahan ingin atasan terbuka dalam menyampaikan informasi penting yang berkaitan dengan instasi dan tidak menutupi diri terhadap bawahannya dalam menyampaikan informasi. Agar tidak ada kesalahpahaman antara atasan dan bawahan dilingkungan kerja".

Dari hasil wawancara diatas menurut penulis menurut penulis saling terbuka dan memahami antara atasan dan bawahan adalah kunci dalam berkomunikasi. Dan apakah dalam menjalin hubungan kerja atasan sudah memberi empati kepada bawahanPenulis juga mewawancarai Kepala BidangMaria Parinusi Sebagai Berikut:

“............Sebagai bawahan saya berharap atasan itu harus bisa mengetahui apa yang sedang dihapi bawahannya pada suatu saat tertentu dengan kata lain atasan dapat memahami apa yang sedang dihadapi bawahannya. Menurut pendapat saya pribadi sendiri, baik itu atasan maupun bawahan atau pegawai disini masih kurang rasa empatinya. Saya belum cukup merasakan sikap empati yang menjadi harapan bawahan, bahwa 
harapan mengenai tindakan nyata belum begitu merata atau dirasakan di Dinas Pemberdayaan Perempuan, Perlindungan Anak dan Keluarga Berencana Kabupaten Supiori. Biasanya disampaikan oleh atasan adalah saran dalam upaya untuk membantu juga memperbaiki pekerjaan yang sedang dilakukan untuk menjadi lebih baik. kemampuan atasan untuk mengetahui apa yang sedang dialami oleh pegawai pada saat-saat tertentu, saya juga sebagai bawahan harus bisa memahami apa yang dirasakan oleh atasan saya. Bukan hanya atasan, tetapi bawahan juga harus memiliki kepedulian yang tinggi karena ini akan berpengaruh pada tujuan yang ingin dicapai instansi'.

Dari hasil wawancara diatas menurut penulis sebagai atasan harus bisa tahu apa yang sedang dihadapi oleh bawahannya dan juga atasan dan bawahannya harus mempunyai rasa empati agar dalam menjalin hubungan kerja antara atasan dan bawahan akan berpengaruh pada tujuan yang ingin dicapai. Dan apakah dalam menjalin hubungan kerja apakah atasan memberi sikap mendukung kepada bawahan. Penulis juga mewawancarai salah satu Staf Yosina Rumsowek sebagai berikut :

“..........Menurut saya dukungan yang diberikan oleh atasan mengenai pekerjaan yang dilakukan pegawai/bawahan selama ini, dapat dilihat dengan adanya pandang yang terbuka dari atasan yaitu mencoba menjelaskan apa yang terjadi dan dirasakan, bersikap terbuka dan terus terang dengan bawahan, selain itu juga bersikap profesionalisme yaitu berpikiran terbuka dan mau mendengar pandangan yang berlawan. Saya sendiri merasa dengan begitu dukungan yang diberikan atasan dalam menjalin komunikasi sangat mendukung saya dalam menjalankan tugas yang diberikan kepada saya. sikap mendukung yang ditunjukan oleh atasan sudah cukup dirasakan, namun masih kurangnya komunikasi dan koordinasi antara sesama pegawai/bawahan menyebabkan sering tidak saling mendukung dan membantu dalam penyelesaian tugas sehingga pekerjaan yang seharunya cepat selesai menjadi terhambat dan tidak selesai pada waktunya'.

Dari hasil wawancara diatas menurut penuliskurangnya komunikasi dan koordinasi antara sesama pegawai/bawahan menyebabkan sering tidak saling mendukung dan membantu dalam penyelesaian tugas. Dan dari atasan sendiri sudah memberikan sikap positif dan kesetaraan dalam menjalin hubungan kerja kepada bawahan. Penulis juga mewawancarai salah satu staf Riki Kurni sebagai berikut;$$
\text { , }
$$

Dalam menjalin hubungan kerja kepada bawahan sikap positif yang ditunjukan atasan yaitu adanya sikap yang lebih mendukung dan memberikan support dan spirit dari atasan kepada bawahan dalam bekerja, selain itu adanya sikap positif untuk mendorong sesama pegawai/bawahan agar lebih semangat lagi dalam bekerja, dengan sikap positif dari atasan saya merasa nyaman dalam bekerja, dan dapat bekerja dengan maksimal. Dan dapat menambah semangat saja dalam menjalankan kewajiban saya sebagai bawahan."Sebenarnya semua karyawan itu sama tapi dengan bagian pekerjaan yang berbeda-beda. Dan selanjutnya bersikap yakin, percaya diri, tidak 
merasa malu, dan gugup dalam menghadapi atasan dan menjaga hubunga dengan sesama pegawai yang berguna bagi kelancaran pekerjaannya masing-masing. Kebersamaan pada rekan kerja yang bagus, baik dan saling memberitahu apabila sesama pegawai belum mengetahui informasi yang belum diketahuinya oleh atasan, sehingga dalam menjalin hubungan kerja sesama pegawai berjalan dengan baik dan selalu ada hubungan timbal balik'.'

Dari hasil penjelasan diatas menurut penulis Hubungan interpersonal antar pimpinan dan staf/bawahan, atau pegawai dengan pegawai dapat dikatakan terjalin dengan intensif ketika melaksanakan tugas, baik pimpinan maupun bawahan mencapai hasil yang optimal sesuai dengan tujuan yang diinginkan. Proses komunikasi yang dilakukan di baik pimpinan maupun pegawai sabaiknya melalui jenjang struktur. Maksudnya jika pimpinan ingin memberikan instruksi atau arahan ataupun teguran kepada bawahan dalam hal ini pegawai, tidak secara langsung memberikan arahan ataupun teguran kepada bawahan tersebut.

\section{B. Keterbukaan}

Sikap terbuka mendorong terbukanya saling pengertian, saling menghargai, saling mengembangkan kualitas hubungan interpersonal. Keterbukaan mengacu pada tiga aspek dari komunikasi interpersonal. Pertama, komunikasi interpersonal yang efektif harus terbuka kepada orang yang diajak berinteraksi. Kedua, mengacu pada kesediaan komunikator untuk berinteraksi secara jujur terhadap stimulus yang datang. Aspek ketiga menyangkut kepemilikan perasaan dan pikiran. Artinya terbuka adalah mengakui bahwa perasaan dan pikiran yang orang lontarkan adalah memang miliknya dan harus dipertanggungjawabkan.

Begitupun yang terjadi di Kantor Dinas Pemberdayaan Perempuan, Perlindungan Anak dan Keluarga Berencana Kabupaten Supiori, pegawai selalu terbuka dalam menyampaikan informasi penting jujur dan terbuka terhadap pimpinan maupun sesama staf/bawaham. Keterbukaan ini ditandai dengan adanya kejujuran serta tidak menyembunyikan informasi yang sebenarnya. Oleh karena itu pegawai diharapkan menciptakan suasana komunikasi yang kondusif.

\section{Empati}

Empati ialah kemampuan seseorang untuk merasakan kalau seandainya menjadi orang lain, dapat memahami sesuatu yang sedang dialami orang lain, dapat merasakan apa yang dirasakan orang lain, dan dapat memahami sesuatu persoalan dari sudut pandang orang lain, melalui kacamata orang lain. Orang yang berempati mampu memahami motivasi dan pengalaman orang lain, perasaan dan sikap mereka, serta hapan dan keingan mereka.

\section{Sikap mendukung (suppotiveness).}

Hubungan interpersonal yang efektif adalah hubungan di mana terdapat sikap mendukung. Artinya masing-masing pihak yang berkomunikasi memiliki komitmen untuk mendukung terselenggaranya interaksi secara terbuka. Dalam lingkungan kerja sikap mendukung adalah sikap atau upaya yang ditunjukan atasan kepada bawahan atau bawahan sesama bawahan dengan memberikan semangat dan perhatian dalam upaya menjalin hubungan kerja yang baik. 


\section{E. Sikap positif}

Sikap positif ditujukan dalam bentuksikap dan prilaku yaitu saling menghargai satu sama lain. Dalam bentuk sikap maksudnya adalah bahwa pihak-pihak yang terlibat dalam komunikasi antar pribadi harus memiliki perasaan dan pikiran positif. Bukan prasangka dan curiga. Dalam bentuk perilaku, artinya bahwa tindakan yang dipilih adalah yang relevan dengan tujuan komunikasi antar pribadi.

\section{KESIMPULAN}

Adapun kesimpulan mengenai Efektifitas Komunikasi Interpersonal Antar Pimpinan Dan Staf Dalam Menjalin Hubungan Kerja Pada Dinas Pemberdayaan Perempuan, Perlindungan Anak Dan Keluarga Berencana kabupaten supiori cukup efektif berdasarkan lima indikator kualitas komunikasi interpersonal yaitu harus memiliki sikap keterbukaan, empati, sikap mendukung, sikap positif dan sikap kesetaraan.

\section{DAFTAR PUSTAKA}

A.A Anwar Prabu Mangkunegara. 2011. Manajement sumber daya manusia peusahan. Bandung: rosda

Burgon \& Huffner. 2002. Human Communication. London: Sage Publication

Devito, Joseph. 1997. Komunikasi Antarmanusia. Professional Books: Jakarta

Effendy, Onong U. (2003). Ilmu Komunikasi Teori dan Praktek. Bandung: PT Remaja Rosdakarya
Effendy, Onong Uchyana. 2011. Ilmu Komunikasi: Teori dan Prakteknya, Bandung : Remaja Rosdakarya

Edwin B. Flippo, 2002. Personal Management, edisi VII Jilid II, Terjemahan Alponso S. Erlangga, jakarta

Hartono, Widodo Dan Judiantoro.1992. Segi Hukum Penyelesaian Perselisihan Perburuan. Jakarta: Rajawali 